\section{Fulminant hepatic failure in acute hepatitis C: increased risk in chronic carriers of hepatitis $B$ virus}

C M Chu, C T Yeh, Y F Liaw

\begin{abstract}
BackgroundlAims-The role of hepatitis C virus (HCV) in fulminant hepatitis remains controversial. This study was conducted to investigate the risk of fulminant hepatitis $\mathrm{C}$ in relation to $\mathrm{HCV}$ genotypes and concurrent infection of other viruses. Patients-109 HCV RNA positive patients from 334 consecutive cases hospitalised to a medical centre in northern Taiwan for overt acute viral hepatitis were prospectively evaluated.

Methods-HCV RNA was detected by a combined reverse transcriptionpolymerase chain reaction assay. $\mathrm{HCV}$ genotypes were analysed using a genotype specific probe based assay in the $5^{\text {, }}$ untranslated region.

Results-39 patients tested positive for hepatitis $B$ surface antigen but negative for IgM antibody to hepatitis $B$ core antigen, indicating concurrent chronic hepatitis $B$ virus (HBV) infection. Twelve patients were hepatitis $G$ virus (HGV) RNA positive. Genotyping of $\mathrm{HCV}$ disclosed $1 b$ in $93,1 b$ mixed with $2 a / 2 c$ or $1 b$ mixed with $2 b$ in 11 , and not classified in five. Serum titres of HCV RNA were $<10^{5}$ copies $/ \mathrm{ml}$ in $77,10^{5}-10^{7}$ copies $/ \mathrm{ml}$ in 25 , and $>10^{7}$ copies $/ \mathrm{ml}$ in seven. Eleven patients $(10.1 \%)$ had fulminant hepatitis as a complication. Development of fulminant hepatitis did not correlate with age and gender of the patients, concurrent HGV infection, HCV genotypes, or serum titre of HCV RNA. However, the incidence (95\% confidence interval) of fulminant hepatitis in patients with underlying chronic HBV infection was $23.1 \%$ (9.9 to $36.3 \%$, which is significantly higher than in those without $(2.9 \%(-1.0$ to $6.8 \%))$. In 39 patients with concurrent chronic HBV infection, the clinical and virological characteristics showed no significant difference between those with fulminant hepatitis and those without.

Conclusions-Acute hepatitis $\mathrm{C}$ in patients with concurrent chronic $\mathrm{HBV}$ infection is associated with a substantial risk of fulminant hepatitis.

(Gut 1999;45:613-617)
\end{abstract}

Keywords: acute hepatitis C; fulminant hepatitis; hepatitis B virus; hepatitis $\mathrm{C}$ virus; hepatitis $\mathrm{G}$ virus

Dr C M Chu, Liver Research Unit, Chang Gung Memorial Hospital, 199 Tung Hwa North Road, Taipei, Taiwan. Viral hepatitis is the most frequent cause of fulminant hepatic failure (FHF). Some $40-$
$60 \%$ of patients with FHF of presumed viral cause have negative serological markers for hepatitis A virus (HAV) and hepatitis B virus (HBV) infection, being classified as non-A non-B (NANB) hepatitis or of indeterminate cause. ${ }^{12}$ Hepatitis $\mathrm{C}$ virus (HCV) has recently been identified as a major agent of parenterally or community acquired NANB hepatitis, ${ }^{3}$ but the role of HCV infection in fulminant NANB hepatitis or fulminant hepatitis of indeterminate cause is controversial. In previously reported series of patients with fulminant NANB hepatitis, the prevalence of serum HCV RNA was low in the United States and Europe $^{4-8}$ but substantially higher in Japan and Taiwan. ${ }^{9}{ }^{10}$ A possible explanation for these apparent discrepancies may be related to the geographical strain difference of HCV: in Oriental countries HCV genotype 1 is the most prevalent, whereas most isolates from Western countries are of HCV genotype $1 \mathrm{a} .{ }^{11}$ On the other hand, a high frequency of serum $\mathrm{HCV}$ RNA positivity was noted in hepatitis B surface antigen (HBsAg) positive patients with FHF from different geographical areas. ${ }^{4-9}$ These findings probably suggest that co-infection with hepatitis $B$ virus (HBV) and $\mathrm{HCV}$ or superinfection of $\mathrm{HCV}$ in chronic carriers of HBV may increase the risk of FHF. Furthermore, an appreciable proportion of patients with acute hepatitis $C$ were found to have concurrent hepatitis $\mathrm{G}$ virus (HGV) infection. ${ }^{12}$ Whether the incidence of FHF in acute hepatitis $\mathrm{C}$ correlates with concurrent $\mathrm{HGV}$ infection also remains to be fully elucidated. This study was prospectively conducted to investigate the incidence of FHF in patients hospitalised for overt acute hepatitis $\mathrm{C}$ in an endemic area of $\mathrm{HBV}$, with special emphasis on its relation to the genotypes of HCV and concurrent HBV or $\mathrm{HGV}$ infection.

\section{Materials and methods}

PATIENTS

This investigation was carried out from July 1995 to June 1997 on 334 consecutive adult patients with acute viral hepatitis admitted to the Department of Internal Medicine, Chang Gung Memorial Hospital and College, a medical centre in northern Taiwan. The diagnosis of

Abbreviations used in this paper: $\mathrm{HCV}$, hepatitis $\mathrm{C}$ virus; $\mathrm{HBV}$, hepatitis $\mathrm{B}$ virus; $\mathrm{HGV}$, hepatitis $\mathrm{G}$ virus; HAV, hepatitis A virus; HDV, hepatitis D virus; FHF, fulminant hepatic failure; RT-PCR, reverse transcription-polymerase chain reaction; NANB, non-A non-B; HBsAg, hepatitis B surface antigen; 
acute hepatitis was based on the lack of previous history of chronic liver disease, the discrete onset of clinical symptoms and signs, and compatible liver biochemical tests. Drug and alcohol abuse were excluded as likely causes.

All patients had serum samples, taken within four weeks of the onset of illness, available for serodiagnosis of acute viral hepatitis. The serum samples were collected on the first day after admission before the administration of any specific treatment including fresh frozen plasma transfusion for patients with severe coagulopathy. The serological tests included IgM class antibody against HAV (IgM anti$\mathrm{HAV}$ ), HBsAg, IgM class antibody against hepatitis B core antigen (IgM anti-HBc), $\operatorname{Ig} M$, and IgG class antibodies against hepatitis D virus (IgM anti-HDV and IgG anti-HDV) if HBsAg was positive, antibodies against $\mathrm{HCV}$ (anti-HCV), IgM class antibody against Epstein-Barr virus capsid antigen (IgM antiEBV), and IgM class antibody against cytomegalovirus (IgM anti-CMV), using commercially available kits. Serum samples were also divided into aliquots and stored at $-70^{\circ} \mathrm{C}$ for HBV DNA, HCV RNA, and HGV RNA assay.

According to the conventional diagnostic criteria, 12 cases were diagnosed as acute hepatitis A because IgM anti-HAV was positive; 17 cases were diagnosed as acute hepatitis $\mathrm{B}$ because $\operatorname{IgM}$ anti-HBc was positive with or without $\mathrm{HBsAg}$, but the possibility of acute exacerbations of chronic HBV infection could not be completely excluded ${ }^{13} ; 128$ cases were diagnosed as acute NANB hepatitis because IgM anti-HAV, HBsAg, IgM anti-HBc, IgM anti-CMV, and IgM anti-EBV all were negative; and 177 cases were diagnosed as chronic hepatitis B with acute exacerbations or viral superinfection because HBsAg was positive but $\operatorname{IgM}$ anti-HBc was negative.

SERODIAGNOSIS OF ACUTE HEPATITIS C

The serodiagnosis of acute hepatitis C was particularly difficult. The presence of anti$\mathrm{HCV}$ in initial acute phase serum samples failed to distinguish between acute and chronic $\mathrm{HCV}$ infection. However, anti-HCV may develop relatively late in the course of infection, and convalescent phase serum samples (more than six months after the onset of illness) were needed for diagnosis of acute hepatitis C. Furthermore, some patients were diagnosed as having acute hepatitis $\mathrm{C}$ solely on the basis of positive HCV RNA without seroconversion of anti-HCV. Of 106 patients with acute hepatitis $\mathrm{C}$ diagnosed by Alter et $a l,{ }^{14} 63$ (59\%) were anti-HCV positive in acute phase serum samples, 30 (28\%) developed anti-HCV more than six months after the onset of illness, and $13(12 \%)$ were HCV RNA positive without seroconversion of anti-HCV. It is noteworthy that HCV RNA was positive in every patient of this series regardless of the status of anti-HCV. ${ }^{14}$ It seems that testing HCV RNA in a single acute phase serum sample could diagnose acute hepatitis $C$ for every patient of the series of Alter et al. Because it was difficult to collect convalescent phase serum samples from all of our study patients, in this study, acute hepatitis $\mathrm{C}$ was diagnosed if the acute phase serum samples were HCV RNA positive, with or without anti-HCV, although the possibility of chronic hepatitis $\mathrm{C}$ with acute exacerbation or a superimposed unrelated form of acute hepatitis cannot be excluded.

LABORATORY METHODS

Serum HBsAg, IgM anti-HBc, IgM anti-HAV, and IgG anti-HDV were assayed using commercially available radioimmunoassay kits (Ausria II, Corab-M, HAVAB-M, and antidelta respectively; Abbott Laboratories, North Chicago, Illinois, USA). IgM anti-HDV was assayed using an enzyme immunoassay (Deltassay IgM; Cambridge Biotech Limited, Dublin, Ireland). IgM anti-CMV was assayed by an enzyme immunoassay (CMV IgM; Merck, Darmstadt, Germany). IgM anti-EBV was assayed by indirect immunofluorescence (EBV IgM; Gull, Saltlake, Utah, USA). Anti-HCV was assayed by second generation enzyme immunoassay (UBI-HCV-EIA; United Biochemical Inc, Lake Success, New York, USA) based on synthetic peptides derived from immunodominant regions of both capsid and non-sturctural HCV proteins. HBV DNA was assayed by spot hybridisation using ${ }^{32} \mathrm{P}$ labelled cloned HBV DNA, as previously described. ${ }^{15}$ The detection sensitivity was $0.5 \mathrm{pg} / 50 \mu \mathrm{l}$. HCV RNA was detected by a combined reverse transcription-polymerase chain reaction (RT-PCR) assay (AMPLICOR HCV test; Roche Diagnostic System Inc, Branchburg, New Jersey, USA). The detection sensitivity of this assay was about $10-100$ copies/ml. HCV genotypes were analysed using a genotype specific probe based assay in the 5' untranslated region (LiPA; Innogenetics, Ghent, Belgium), which can identify the five major genotypes and other subtypes (1a, 1b, 2a/2c, 2b, 3a, 3b, 4, and 5a). Serum titres of HCV RNA were determined using RT-PCR followed by slot/blot hybridisation with a digoxigenin labelled probe, as previously described in detail. ${ }^{16}$ This assay was shown to be comparable with the commercial branched DNA assay (QUANTIPLEX HCV RNA 2.0 assay; Chiron, Emeryville, California, USA), and serum concentrations of HCV RNA above $10^{5}$ copies $/ \mathrm{ml}$

Table 1 Results of clinical and laboratory tests of 11 hepatitis $C$ virus (HCV) RNA positive patients with fulminant hepatitis

\begin{tabular}{|c|c|}
\hline Clinical/laboratory tests & Results \\
\hline Age (years) & $42.1(5.8)$ \\
\hline Male/female & $8: 3$ \\
\hline No of cases with chronic HBV infection ${ }^{\star}$ & 9 \\
\hline No of cases with fulminant $v$ subfulminant form $\dagger$ & $6 v 5$ \\
\hline Albumin $(\mathrm{g} / \mathrm{l}$, normal >35) & $28.3(2.4)$ \\
\hline Globulin (g/1, normal <35) & $32.4(7.2)$ \\
\hline AST $(\mathrm{U} / 1$, normal $<40)$ & $1163(244)$ \\
\hline $\operatorname{ALT}(\mathrm{U} / 1$, normal $<40)$ & $1432(268)$ \\
\hline Bilirubin $(\mu \mathrm{mol} / 1$, normal $<17)$ & $452(156)$ \\
\hline Prothrombin time (seconds prolonged) & $20.7(7.3)$ \\
\hline
\end{tabular}

Where applicable, data are expressed as mean (SEM). ${ }^{\star}$ Those who were $\mathrm{HBs} A g$ positive but IgM anti-HBc negative during presentation of acute hepatitis. †Fulminant and subfulminant hepatic failure were diagnosed according to the definition by Bernuau et al. ${ }^{2}$

HBV, hepatitis B virus; AST, serum aspartate aminotransferase; ALT, serum alanine aminotransferase; HBsAg, hepatitis B surface antigen. 
Table 2 Risk factors of fulminant hepatic failure in acute hepatitis $C$

\begin{tabular}{|c|c|c|c|}
\hline Risk factors & $\begin{array}{l}\text { Fulminant } \\
(n=11)\end{array}$ & $\begin{array}{l}\text { Non-fulminant } \\
(n=98)\end{array}$ & Odds ratio $(95 \% \mathrm{CI})$ \\
\hline \multicolumn{4}{|l|}{ Age } \\
\hline$\leqslant 40 y$ & 36 & 34 & 1.00 \\
\hline$>40 \mathrm{y}$ & 64 & 66 & $0.89(0.25 \text { to } 3.19)^{\star}$ \\
\hline \multicolumn{4}{|l|}{ Sex } \\
\hline Male & 73 & 60 & 1.00 \\
\hline Female & 27 & 40 & $0.57(0.14 \text { to } 2.24)^{\star}$ \\
\hline \multicolumn{4}{|l|}{ HCV genotype } \\
\hline $1 \mathrm{~b}$ & 82 & 86 & 1.00 \\
\hline $1 b+2 a$ or $1 b+2 b$ & 18 & 9 & $2.07(0.40 \text { to } 10.72)^{\star}$ \\
\hline Not classified & 0 & 5 & $0.81(0.46 \text { to } 1.42)^{\star}$ \\
\hline \multicolumn{4}{|c|}{ Serum levels of HCV RNA } \\
\hline$<10^{5}$ copies $/ \mathrm{ml}$ & 73 & 70 & 1.00 \\
\hline $10^{5}-10^{7}$ copies $/ \mathrm{ml}$ & 27 & 23 & $1.18(0.28 \text { to } 4.96)^{\star}$ \\
\hline$>10^{7}$ copies $/ \mathrm{ml}$ & 0 & 7 & $0.55(0.15 \text { to } 2.02)^{\star}$ \\
\hline \multicolumn{4}{|c|}{ Concurrent HGV infection } \\
\hline Negative & 91 & 89 & 1.00 \\
\hline Positive & 9 & 11 & $0.79(0.09 \text { to } 6.84)^{\star}$ \\
\hline \multicolumn{4}{|c|}{ Concurrent HBV infection } \\
\hline Negative & 18 & 69 & 1.00 \\
\hline Positive & 82 & 31 & $10.20(4.74$ to 21.95$) \dagger$ \\
\hline
\end{tabular}

Results are expressed as percentages.

${ }^{\star} \mathrm{p}>0.2,+\mathrm{p}<0.01$ by the $\chi^{2}$ test with Yates' correction.

$\mathrm{HCV}$, hepatitis $\mathrm{C}$ virus; HBV, hepatitis B virus; HGV, hepatitis $\mathrm{G}$ virus.

could be quantitatively determined. ${ }^{16} \mathrm{HGV}$ RNA was detected by PCR with specific primers derived from the 5 , untranslated region of $\mathrm{HGV}$, as described by Kao et al. ${ }^{17}$

STATISTICAL ANALYSIS

Statistical analyses were conducted using the $\chi^{2}$ test with Yates' correction and odds ratio where appropriate.

\section{Results}

A total of 109 (32.6\%) of 334 study patients were positive for HCV RNA and were considered to have acute hepatitis C. Of these, 37 $(34 \%)$ were positive for anti-HCV with signal to cut off ratios of less than 3.0. None of the patients with acute hepatitis A or B were HCV RNA positive, while HCV RNA was detected in $70(54.7 \%)$ of 128 patients with acute NANB hepatitis and $39(22.0 \%)$ of 177 pre-

Table 3 Characteristics of the HBs Ag carriers with superimposed acute hepatitis C: comparison between those with a fulminant course and those with a non-fulminant course

\begin{tabular}{|c|c|c|}
\hline Characteristics & $\begin{array}{l}\text { Fulminant } \\
(n=9)\end{array}$ & $\begin{array}{l}\text { Non-fulminant } \\
(n=30)\end{array}$ \\
\hline \multicolumn{3}{|l|}{ Age } \\
\hline$\leqslant 40 \mathrm{y}$ & 44 & 63 \\
\hline$>40 \mathrm{y}$ & 56 & 37 \\
\hline \multicolumn{3}{|l|}{ Sex } \\
\hline Male & 89 & 73 \\
\hline Female & 11 & 27 \\
\hline \multicolumn{3}{|l|}{ HCV genotypes } \\
\hline $1 \mathrm{~b}$ & 78 & 83 \\
\hline $1 b+2 a / 2 c$ or $1 b+2 b$ & 22 & 10 \\
\hline Not classified & 0 & 7 \\
\hline \multicolumn{3}{|l|}{ Serum titres of HCV RNA } \\
\hline$<10^{5}$ copies $/ \mathrm{ml}$ & 78 & 73 \\
\hline $10^{5}-10^{7}$ copies $/ \mathrm{ml}$ & 22 & 27 \\
\hline Concurrent HGV infection & 11 & 10 \\
\hline Concurrent HDV infection & 22 & 7 \\
\hline \multicolumn{3}{|l|}{ Serum levels of HBV DNA } \\
\hline Undetectable & 44 & 50 \\
\hline $10-100 \mathrm{pg} / \mathrm{ml}$ & 11 & 10 \\
\hline $101-1000 \mathrm{pg} / \mathrm{ml}$ & 11 & 17 \\
\hline$>1000 \mathrm{pg} / \mathrm{ml}$ & 33 & 23 \\
\hline
\end{tabular}

Results are expressed as percentages.

$p>0.2$ by the $\chi^{2}$ test with Yates' correction for all comparisons between patients with a fulminant course and those with a nonfulminant course.

HBsAg, hepatitis B surface antigen; HCV, hepatitis C virus; HGV, hepatitis G virus; HDV, hepatitis D virus. viously unrecognised chronic HBsAg carriers with superimposed acute hepatitis. Thirty nine (35.8\%) of 109 patients with acute hepatitis C thus had concurrent chronic HBV infection.

Of these 109 patients, 67 were men and 42 were women (age range 19-79 years ( $\leqslant 40$ years for 37 and $>40$ years for 72$)$ ). None had a history of blood transfusion, tatooing, acupucture surgery, or dental procedures within the six months before the onset of acute hepatitis, and none admitted to homosexual activity or intravenous drug abuse. Genotyping of HCV disclosed $1 \mathrm{~b}$ in 93, $1 \mathrm{~b}$ mixed with $2 \mathrm{a} / 2 \mathrm{c}$ or $1 \mathrm{~b}$ mixed with $2 \mathrm{~b}$ in 11 , and not classified in five. Serum titres of HCV RNA were $<10^{5}$ copies $/ \mathrm{ml}$ in $77,10^{5}-10^{7}$ copies $/ \mathrm{ml}$ in 25 , and $>10^{7}$ copies $/ \mathrm{ml}$ in seven. Twelve patients (11\%) had concurrent HGV infection.

Eleven patients $(10.1 \%)$ had the complication of FHF according to the definition proposed by Bernuau et al. ${ }^{2}$ Table 1 gives a summary of the results of their detailed clinical and laboratory tests. All received only supportive care, and 10 patients died. None had a liver biopsy because of severe coagulopathy. As shown in table 2, the incidence of FHF did not correlate with age and gender of the patients, the distribution of HCV genotypes, serum titre of HCV RNA, or the presence of concurrent $\mathrm{HGV}$ infection. In contrast, the occurrence of FHF was closely related to concurrent chronic $\mathrm{HBV}$ infection. The incidence of FHF in patients with underlying chronic HBV infection was $23.1 \%$ (9/39), which is significantly $(\mathrm{p}<0.01)$ higher than in those without $(2.9 \%$ or $2 / 70)$.

Of the 39 HBsAg carriers with superimposed acute hepatitis C, 30 were men and nine were women, and their mean ages were 40.8 years ( $\leqslant 40$ years for 23 and $>40$ years for 16). Genotypes of HCV included $1 \mathrm{~b}$ in $32,1 \mathrm{~b}$ mixed with $2 \mathrm{a} / 2 \mathrm{c}$ or $1 \mathrm{~b}$ mixed with $2 \mathrm{~b}$ in five, and not classified in two. Serum titres of HCV RNA were $<10^{5}$ copies $/ \mathrm{ml}$ in 29 and $10^{5}-10^{7}$ copies $/ \mathrm{ml}$ in 10 . Serum levels of HBV DNA were undetectable in $19,10-100 \mathrm{pg} / \mathrm{ml}$ in four, $101-1000 \mathrm{pg} / \mathrm{ml}$ in six, and $>1000 \mathrm{pg} / \mathrm{ml}$ in 10 . Four patients had concurrent $\mathrm{HGV}$ infection (HGV RNA positive) and another four had concurrent HDV infection (IgG and IgM antiHDV positive). The clinical and virological characteristics on admission showed no significant difference between those with a fulminant course and those with a non-fulminant course (table 3).

\section{Discussion}

Taiwan is an area with endemic HAV and HBV infection. Nearly $95 \%$ and $85 \%$ of adults in the general population were found to have serological markers of HAV and HBV respectively. ${ }^{18} 19$ In keeping with these epidemiological data, only a few cases of acute viral hepatitis in this series could be attributed to acute hepatitis A or B, whereas $30-40 \%$ of the cases were possibly due to NANB hepatitis and the remaining $50-60 \%$ were previously unrecognised HBsAg carriers with re-activation of HBV or superinfection with non-B viruses. These findings are similar to our previous 
observations in this area. ${ }^{20}$ Furthermore, the present results indicate that about one third of patients with acute viral hepatitis were $\mathrm{HCV}$ RNA positive, including $50-60 \%$ of patients with acute NANB hepatitis and $20-25 \%$ of chronic HBsAg carriers with superimposed acute hepatitis. Although the only definite method of diagnosing acute $\mathrm{HCV}$ infection is to have longitudinal data showing the absence of hepatitis $\mathrm{C}$ before the episodes of acute hepatitis, the presence of serum HCV RNA in patients with acute viral hepatitis may be highly suggestive of acute HCV infection. However, the possibility of chronic hepatitis $\mathrm{C}$ with acute exacerbation or a superimposed unrelated form of acute hepatitis cannot be excluded. Notably, only about one third of HCV RNA positive patients with acute viral hepatitis in this series were positive for anti-HCV by second generation enzyme immunoassay, and all had signal to cut off ratios of less than 3.0. These findings may be compatible with acute rather than chronic $\mathrm{HCV}$ infection.

Eleven $(10 \%)$ of 109 patients in hospital for overt acute hepatitis $\mathrm{C}$ in this series had the complication of FHF. As shown in table 2, the occurrence of FHF in acute $\mathrm{HCV}$ infection did not correlate with age and gender of the patients. The genotypes of HCV also showed no significant difference between patients with FHF and those without. However, it should be pointed out that, in keeping with previous epidemiological data indicating that HCV genotype $1 \mathrm{a}$ is extremely rare in the Far East, ${ }^{11}$ no patients in this series were infected with genotype $1 \mathrm{a}$. It thus remains uncertain whether the risk of FHF in acute $\mathrm{HCV}$ infection differs between the predominant strain of Western countries (genotype 1a) and that of Oriental countries (genotype 1b). Notably, about 10\% of patients with acute $\mathrm{HCV}$ infection in the present series had a mixed infection with two strains of $\mathrm{HCV}$, which was not associated with an increased risk of FHF. In this study also, the occurrence of FHF in acute hepatitis $\mathrm{C}$ did not correlate with serum titres of HCV RNA, which even tended to be higher in patients with non-fulminant hepatitis, although the difference did not reach statistical significance (table 2). Furthermore, these results indicate that the incidence of $\mathrm{FHF}$ in acute hepatitis $\mathrm{C}$ was not related to concurrent $\mathrm{HGV}$ infection. Perhaps the most important finding is that the incidence of FHF in acute HCV infection correlates significantly with concurrent chronic HBV infection. The current data thus show for the first time that acute HCV infection superimposed upon chronic HBV infection significantly increases the risk of FHF.

Two (3\%) of 70 patients admitted for overt acute hepatitis $\mathrm{C}$ who were not chronic HBsAg carriers in the present series had FHF. This figure is very close to those reported previously for patients hospitalised for overt acute NANB hepatitis in Greece ${ }^{21}$ and Taiwan ${ }^{22}$ : six $(2.4 \%)$ of 251 patients and three $(2.4 \%)$ of 124 patients respectively had FHF. It is noteworthy that, in a large series of 550 patients with transfusion associated NANB hepatitis, none developed FHF. ${ }^{23}$ Furthermore, none of the cases of fulminant hepatitis $\mathrm{C}$ in the present series as well as in the previous series ${ }^{910}$ were transfusion related. Whether the severity of acute hepatitis C correlates with the mode of transmission requires further investigation. On the other hand, in most cases of transfusion related NANB hepatitis reported previously, there was asymptomatic elevation of serum transaminase levels which was identified during regular follow up, whereas all patients with acute hepatitis $\mathrm{C}$ in the present series or acute NANB hepatitis in the previous series ${ }^{21} 22$ had overt symptoms of acute hepatitis which warranted medical attention and hospitalisation. The high incidence of FHF in the present series and in the previous series of patients with acute NANB hepatitis ${ }^{212}$ may be related to the selective hospitalisation of the most severe clinical cases.

Nine $(23 \%)$ of 39 patients with overt acute hepatitis C superimposed upon chronic HBV infection had FHF complications. This figure is about 10 -fold higher than in those who had no chronic HBV infection (table 2). The impact of underlying chronic HBV infection on the outcome of acute viral hepatitis has been shown in an outbreak of hepatitis A in Shanghai in 1982: the fatality rate for hepatitis A in patients with chronic HBV infection is 5.6-fold higher than in those who were not HBsAg carriers (see review by Keeffe ${ }^{24}$ ). An analysis of cases of acute hepatitis A in the United States from 1983 to 1988 also provides data that appear to support the findings from the Shanghai epidemic even more strongly: the fatality rate for acute hepatitis A in HBsAg carriers is $11.7 \%$, which is about 58 -fold higher than in patients who were not HBsAg carriers. $^{24}$ Furthermore, a recent study reported by Vento and coworkers ${ }^{25}$ from Italy indicated that patients with chronic hepatitis $\mathrm{C}$ had a substantial risk of FHF and death associated with HAV superinfection. Taken together, these data strongly suggest the potential impact of underlying chronic liver disease on the outcome of acute viral hepatitis. Notably, in the series of Vento et al, all patients with FHF had chronic hepatitis $\mathrm{C}$ but not cirrhosis; thus the liver parenchyma was still relatively well preserved and liver failure was not due to the severity of the pre-existent liver disease. ${ }^{25}$

As shown in table 3, the incidence of FHF in $\mathrm{HbsAg}$ carriers with acute hepatitis $\mathrm{C}$ was not related to age and gender of the patients, $\mathrm{HCV}$ genotype, concurrent HGV or HDV infection, or serum titre of HBV DNA and HCV RNA on admission. However, it remains unknown whether the risk of FHF correlates with the pre-existent HBV replication status or liver histopathological changes, because these patients were first recognised as HBsAg carriers (HBsAg positive but IgM anti-HBc negative) during the present episodes of acute hepatitis. Although all patients in the present series were in good health and none had evidence of chronic liver disease on clinical grounds, asymptomatic HBsAg carriers are known to harbour various liver lesions that might aggravate the severity of acute hepatitis. These patients would not be considered to have FHF 
according to the criteria of Trey and Davidson, ${ }^{26}$ but the occurrence of acute hepatic failure in previously asymptomatic patients with chronic liver disease has been included in the more recent definition of FHF. ${ }^{12}$ On the other hand, the severity of acute viral hepatitis has been suggested to be dependent on the host immune factor. It has long been suggested that HBsAg carriers are immunologically different from non-carriers. For instance, HBsAg carriers have been reported to have impaired cell mediated immunity, ${ }^{27}$ decreased peripheral blood $\mathrm{T}$ cells with reversed inducer/helper to suppressor/cytotoxic $\mathrm{T}$ cell ratios, ${ }^{28}$ impaired interferon production, ${ }^{29}$ and, possibly, other yet unrecognised differences. These differences may contribute to the development of FHF in HBsAg carriers. Alternatively, hepatocytes harbouring HBV may be unusually susceptible to necrotic damage by a new virus or may be limited in their ability to regenerate. All these postulations are speculative and need to be elucidated in further studies. Nevertheless, the most important clinical implication of this study is that asymptomatic HBsAg carriers are not only at an increased risk of liver cirrhosis and/or hepatoma, but are much more likely to die from FHF if they contract acute hepatitis.

In conclusion, about one third of cases of adult patients hospitalised for overt acute viral hepatitis in Taiwan could be attributed to acute $\mathrm{HCV}$ infection. Of these, $36 \%$ had underlying chronic HBV infection. Acute hepatitis C superimposed on chronic HBV infection was associated with a high risk of FHF.

Grant support was received from the National Institute of Health (DOH85-HR-522) and the National Science Council (NSC87-2315-B-182-003-MH). The authors thank Ms S C Chen for preparation of the manuscript.

1 O'Grady JG, Schalm SW, Williams R. Acute liver failure: redefining the syndromes. Lancet 1993;342:273-5.

2 Bernuau J, Rueff B, Benhamou JP. Fulminant and subfulminant liver failure: definitions and causes. Semin Liver Dis 1986;6:97-106.

3 Kuo G, Choo QL, Alters HJ, et al. An assay for circulating antibodies to a major etiologic virus of human non-A non-B hepatitis. Science 1989;244:362-4.

4 Wright TL, Mamish D, Combs C, et al. Hepatitis B virus and apparent fulminant non-A, non-B hepatitis. Lancet 1992;339:952-5.

5 Liang TJ, Jeffers L, Reddy RK, et al. Fulminant or subfulminant non-A, non-B viral hepatitis: the role of hepatitis $C$ and $\mathrm{E}$ viruses. Gastroenterology 1993;104:556-62.

6 Féray C, Gigou M, Samuel D, et al. Hepatitis C virus RNA and hepatitis B virus DNA in serum and liver of patients with fulminant hepatitis. Gastroenterology 1993;104:54955 .
7 Theilmann L, Sobach C, Toex U, et al. Role of hepatitis C virus infection in German patients with fulminant and subacute hepatic failure. Eur f Clin Invest 1992;22:569-71.

8 Sallie R, Silva AE, Purdy M, et al. Hepatitis C and E in non-A non-B fulminant hepatic failure: a polymerase chain reaction and serological study. F Hepatol 1994;20:580-8.

9 Yanagi M, Kaneko S, Unoura M, et al. Hepatitis C virus in fulminant hepatic failure [letter]. N Engl f Med 1991;324: 1895-6.

10 Chu CM, Sheen IS, Liaw YF. The role of hepatitis C virus in fulminant viral hepatitis in an area with endemic hepatitis A and B. Gastroenterology 1994;107:189-95.

11 Takada N, Takase S, Takada A, et al. Differences in the hepatitis $\mathrm{C}$ virus genotypes in different countries. 7 Hepatol 1993;17:277-83.

12 Dawson GJ, Shlauder GG, Pilat-Matias TJ, et al. Prevalence of GB virus-C infection using reverse transcriptasepolymerase chain reaction. F Med Virol 1996;50:97-103.

13 Chu CM, Liaw YF, Yang CY, et al. Diagnosis of acute type $\mathrm{B}$ hepatitis by a solid phase $\mathrm{u}$-antibody capture radioimmunoassay for IgM class antibody to hepatitis B core antigen: a diagnostic proposal based on a prospective study. Liver 1987;7:182-7.

14 Alter MJ, Margolis HS, Krawtzynski K, et al. The natural history of community acquired hepatitis $\mathrm{C}$ in the United States. N Engl F Med 1992;327:1899-905.

15 Chu CM, Karayiannis P, Fowler MJF, et al. Natural history of chronic hepatitis B virus infection in Taiwan: studies of hepatitis B virus DNA in serum. Hepatology 1985;5:431-4.

16 Yeh CT, Shyu WC, Sheen IS, et al. Quantitative assessment of hepatitis $\mathrm{C}$ virus RNA by polymerase chain reaction and digoxigenin detection system: comparison between branched DNA assay. $\mathcal{F}$ Virol Methods 1997;65:219-26.

17 Kao JH, Chen PJ, Chen W, et al. Amplification of GB virus$\mathrm{C} /$ hepatitis $\mathrm{G}$ virus RNA with primers from different regions of the viral genome. $\mathcal{F}$ Med Virol 1997;51:284-9.

$18 \mathrm{Wu}$ JS, Chen $\mathrm{CH}$, Chiang $\mathrm{YH}$, et al. Hepatitis A virus in Taiwan. F Formos Med Assoc 1980;79:694-9.

19 Sung JL, Chen DS, Lai MY, et al. Epidemiological study on hepatitis B virus infection in Taiwan. Chinese fournal of Gastroenterology 1984;1:1-9.

20 Chu CM, Sheen IS, Liaw YF. The etiology of acute hepatitis in Taiwan: acute hepatitis superimposed on HBsAg carrier state as the main etiology of acute hepatitis in areas with high HBsAg carrier state. Infection 1988;16:233-7.

21 Papalvangelou G, Tassopoulos N, Roumeliotou-Karayannis A, et al. Etiology of fulminant viral hepatitis in Greece. Hepatology 1984;4:369-72.

22 Chu CM, Liaw YF. The incidence of fulminant hepatic failure in acute viral hepatitis in Taiwan: increased risk in patients with pre-existing HBsAg carrier state. Infection 1990;18:200-3.

23 Dienstag JL. Non-A, non-B hepatitis. I. Recognition, epidemiology, and clinical features. Gastroenterology 1983;85: 439-62.

24 Keeffe EB. Is hepatitis A more severe in patients with chronic hepatitis B and other chronic liver diseases. Am 7 Gastroenterol 1995;90:201-5.

25 Vento S, Garofano T, Renzini C, et al. Fulminant hepatitis associated with hepatitis A virus superinfection in patients with chronic hepatitis C. N Engl f Med 1998;338:286-90.

26 Trey C, Davidson C. The management of fulminant hepatic failure. Prog Liver Dis 1970;3:282-98.

27 Dudley F, Fox J, Sherlock RA. Cellular immunity and hepatitis associatd (Australia) antigen liver disease. Lancet 1972;: : $743-6$.

28 Chu CM, Liaw YF. Peripheral T-cell subsets in asymptomatic hepatitis B virus carriers. Cell Immunol 1986;98:5337 .

29 Ikeda T, Lever AML, Thomas HC. Evidence for a deficiency of interferon production in patients with chronic hepatitis B virus infection acquired in adult life. Hepatology 1986;6:962-5. 